\title{
RECQL5 Gene
}

National Cancer Institute

\section{Source}

National Cancer Institute. RECQL5 Gene. NCI Thesaurus. Code C26493.

This gene plays a role in the regulation of DNA topology. 